\title{
Governing Cities for Sustainability: A Research Agenda and Invitation
}

\author{
James Evans* \\ Department of Geography, University of Manchester, Manchester, United Kingdom
}

Keywords: urban governance, decision-making, urban technologies, urbanization dynamics, policy, urban research methodology

Eighty-five per cent of humanity-some nine billion people-will live in cities by the end of this century (OECD Publishing, 2015). While uncertainty surrounds any attempt to look this far into the future, an unquestionable consequence of this oft quoted statistic is that securing the sustainability of our planet is increasingly an urban challenge. Environmental protection, green economic growth, social equality, clean energy, decarbonization, mobility, and health are all best addressed in cities (Short, 2017; Bai et al., 2018). If cities can become sustainable, then we will have gone a long way to fixing many of the problems that we and our fellow species face. The question of course is how to do this. While we now know what the core problems and many of their solutions are, change is not happening at anywhere near the scale and pace required. Cities need to rapidly curb greenhouse gas emissions, reinvent their economies, and address growing inequalities, all in the face of obdurate infrastructures and buildings, huge demographic shifts, rapidly evolving technologies and hostile funding conditions.

As the practice of organizing collective action to steer society toward specific shared goals

OPEN ACCESS

Edited by:

Gregory Patrick Trencher,

Tohoku University, Japan

Reviewed by:

David Gibbs,

University of Hull, United Kingdom

Rider Foley,

University of Virginia, United States

${ }^{*}$ Correspondence:

James Evans

James.Z.Evans@manchester.ac.uk

Specialty section:

This article was submitted to Governance and Cities,

a section of the journal

Frontiers in Sustainable Cities

Received: 19 March 2019

Accepted: 14 May 2019

Published: 04 June 2019

Citation:

Evans J (2019) Governing Cities for Sustainability: A Research Agenda and Invitation.

Front. Sustain. Cities 1:2.

doi: 10.3389/frsc.2019.00002 (Kooiman, 1993), governance is critical in enabling cities to address these challenges. Governments, communities, NGOs, private companies, utilities, universities, unions, and others are realizing the need to work collectively to respond to the pace, scale and scope of urban change. UN Habitat recognizes that working with cities is the best way to address global challenges (Parnell, 2016; Acuto, 2018), while the OECD Publishing (2015) highlights that good governance is particularly crucial in cities due to their density of connections and role as key drivers of development. The focus of governance on who is involved in making decisions and what kinds of knowledge gets to count fundamentally frames what is and is not possible in cities, and by extension enables us to understand how they might be reconfigured to make more sustainable actions possible. Governance underpins the UN Sustainable Development Goals through the enabling goal 17 on strengthening partnerships, while cities have emerged as leaders in the field of climate action through networks such as the C40 Cities Climate Leadership Group, which connects 90 of the world's most influential cities, representing more than 650 million people and one quarter of the global economy. The importance of cities to the sustainability agenda is further heightened by the resurgence of populist national governments around the world that are apathetic or openly hostile to the environmental agenda. The future sustainability of humankind, in both the mundane sense of how day-to-day existence will be for the majority of us to the viability of the planet itself, will be shaped in and by cities. Understanding cities and how they can be governed in more innovative, inclusive and effective ways is now a global sustainability priority in ways that it has not been before.

The Governance and Cities section of Frontiers in Sustainable Cities is the first journal section to focus explicitly on governance for urban sustainability, and its goal is to understand and advance cutting-edge developments in this field from around the world. Here, in this inaugural editorial, I pick out three themes that distinguish this research agenda in the current era: the emergence of new forms of governance, the governance of new technologies, and the importance of collaborative research approaches. These themes are based on 20 years' experience working in the field, engaging with hundreds of academic and non-academic organizations across Europe, America, and Asia, 
and have been added to by our editorial board which itself includes scholars from across the world. They highlight current trends in governance that have emerged as being of particular importance to urban sustainability, and are intended to be broad enough to engage the wide range of approaches and disciplines that have important contributions to make to this agenda. They are certainly not intended to be either exhaustive or exclusive, but rather to provide an invitation to the global community of urban researchers and practitioners to challenge the research agenda on sustainable cities and governance and develop it in new directions.

The first theme concerns the potential for new forms of urban governance to create more sustainable cities. Governance reflects broader societal transformations and is evolving as rapidly and diversely as cities themselves (Cars et al., 2017; Castán Broto et al., 2019). Innovative forms of governance are emerging that involve not just traditional policy interventions from government but new groups, roles, incentives, and cross-sectoral and crossscalar linkages both within, beyond and between cities. These measures range from radical attempts to address social and ecological justice through to new financial instruments and devolved powers that create governance opportunities at new scales. Their ability to shape sustainability varies across different sectors and this Cities and Governance section welcomes contributions from transport studies, planning studies, ecology, energy studies, and business studies that engage critically with the governance of these sectors in urban settings. How sustainability concerns become embedded in policy and decision-making, including whose knowledge gets to count, and the relationships between urban governance, development, policy-making and regulation at different spatial and temporal scales shapes how effective governance can be in creating progressive urban change (Bulkeley and Betsill, 2005; Chatterji, 2013). These concerns lie at the heart of disciplines like public administration and policy studies but also invite a broader range of thinking around transformation. How do approaches like transition studies and resilience thinking help us understand the ways in which urban change takes place? How do cities learn from one another, especially through global urban networks?

The emergence of new scales, speeds and forms of urbanization invites us to unpack and expand the conceptual lexicon of urban governance. By 2100, Lagos will be home to 80 million people. The population of Kampala, capital of Uganda, is predicted to grow more than 10-fold in this period (Hoornweg and Pope, 2017). Yet for all the headlines that megacities grab, half of humanity will live in cities of less than half a million in 2100, and some cities around the world are shrinking. Hosting research on cities in the Global North and Global South (and mixtures of them) is integral to the mission of the Governance and Cities section, including contributions from development studies, postcolonial studies, and gender studies that examine the different contexts in which urban governance plays out and how it is entwined with different kinds of legacies and landscapes. Looking into the future, imaginaries of future cities, orbiting cities, floating cities, and online cities offer different ways to escape or adapt to global ecological crises for various portions of humanity. Each conjures visions of society and technology that make explicit or implicit assumptions about how they should be governed and, as a result, who and what are included or excluded. Long-term political, economic, and environmental trajectories shape governance in markedly different ways in different parts of the world, and articles that engage with this diversity from historical, contemporary, and anticipatory perspectives are welcome.

The second theme concerns the governance of new technologies, specifically in relation to their potential to positively and negatively impact sustainability. Digital services and their impacts are spatially concentrated in cities, layered onto existing uneven geographies (Karvonen et al., 2018). They rely on and feed into wider urbanization dynamics, shaping everyday interactions and restructuring social, economic, and environmental interactions. This theme is interested in how digital technology makes new forms of governance, politics and planning possible, bringing data and monitoring logics to the fore and connecting people, governments and resources in new and potentially more efficient ways (Trencher, 2019). At the same time it is also interested in limitations of technologies to secure urban sustainability, and the uncertainties surrounding how they can and should be governed (Martin et al., 2018). For example, personal data both enables a participatory city with efficient and personalized services, and a surveillance city in which divisions between populations are policed in more invasive ways than ever before (Kitchin, 2014). Autonomous vehicles may radically challenge the way cities are used and designed, reducing the need for private car ownership, accelerating the shift to electric propulsion and halving the number of private passenger vehicles (Milakis et al., 2017). Conversely they may enable super-commuting, release pent up demand for car use and increase emissions and traffic congestion (Lim and Taeihagh, 2018). Cities are where future technologies are being developed and tested, with often mixed results for sustainability (Cugurullo, 2016). What new forms of governance like urban living labs or autonomous decision-making are emerging around these technologies (Karvonen and Van Heur, 2014; Marvin et al., 2018)? How are technologies blurring neat boundaries between formal and informal infrastructures, and can we draw on theorizations of technology and power to critically understand their implications for urban governance? How can approaches from platform studies, future studies, critical data studies, and development informatics help understand the implications of digital technology for urban societies and the governance of cities? The Cities and Governance section is interested in how technology is both shaping and shaped by practices and regimes of governance, and how governance can steer highly uncertain outcomes associated with existing and future technologies in more sustainable directions.

The third theme is methodological, concerning how we research cities and governance. Urban governance is complex, involving numerous partners often with little pre-specified idea of how to achieve shared goals, and a core ambition of the Cities and Governance section is to expand the methodological repertoire of urban governance research to capture these messy realities. Papers are encouraged that describe or are based on innovative methods and research approaches 
that capture perspectives from practitioners, policy-makers, engineers, ecologists, citizens, artifacts, and nonhumans, at and across multiple scales and sectors (Elmqvist et al., 2018). Part of this task involves expanding the range of research settings and approaches, from ethnographies of social and institutional practices through to the use of big data and global network analysis. Capturing the processes of governance in more complete and systematic ways will enable researchers to better evaluate its success in sustainability terms. Writing thirty years ago, David Harvey (1989) lamented the rise of urban governance itself as a symptom of neoliberal funding cuts that forced cities to be more entrepreneurial. Ten years later Kearns and Paddison (2000) editorial, titled "New Challenges for Urban Governance," highlighted the positive potential of urban governance to generate context specific solutions to challenges that are increasingly unmanageable in a traditional top-down style. The fact that this polarity still characterizes much of the debate on urban governance reflects a paucity of robust and critical evaluations of the sustainability outcomes of different types of governance in different urban settings.

Urban governance research is especially suited to coproductive approaches that collapse traditional distinctions between research and action by designing, executing and applying research with non-academic partners (Patel et al., 2015). Practitioners and researchers can be linked more deeply by embedding researchers in local municipalities and vice versa (Polk and Kain, 2015). A profusion of experiments with governance itself is privileging learning from real world demonstrations and sharing knowledge across urban networks as the route to sustainable urban transformation (Valkering et al., 2013; Evans et al., 2016). Organizations involved in urban sustainability lack funding, know-how and capacity to fill their evidence gaps, while universities have huge resources of time and expertise. Globally there will be around 49 billion hours of student time that could be applied to sustainability challenges by 2025 (Evans et al., 2015). We are currently a long way from achieving this and the Cities and Governance section welcomes practical and critical contributions focusing on university-city sustainability initiatives that develop our understanding and awareness about the different ways in which universities can deploy their expertise and capacity to help govern cities more sustainably (Trencher et al., 2014).

\section{REFERENCES}

Acuto, M. (2018). Engaging With Global Urban Governance. Doing Global Urban Research. London: Sage, pp.96-109.

Bai, X., Dawson, R. J., Ürge-Vorsatz, D., Delgado, G. C., Salisu Barau, A., Dhakal, S., et al. (2018). Six research priorities for cities and climate change. Nature 555, 23-25. doi: 10.1038/d41586-018-02409-z

Bulkeley, H., and Betsill, M. (2005). Rethinking sustainable cities: multilevel governance and the 'urban' politics of climate change. Environ. Politics 14, 42-63. doi: 10.1080/0964401042000310178

Cars, G., Healey, P., Madanipour, A., and De Magalhaes, C. (eds) (2017). Urban Governance, Institutional Capacity and Social Milieux. London: Routledge.

Castán Broto, V., Trencher, G., Iwaszuk, E., and Westman, L. (2019). Transformative capacity and local action for urban sustainability. Ambio 48, 449-462. doi: 10.1007/s13280-018-1086-Z
As the first dedicated research journal on the topic of governance for urban sustainability, it gives me and the editorial board great pleasure to warmly invite contributions that develop, extend, question, and diverge from this research agenda. New thinking and practices are required to achieve the scale and pace of urban change required to achieve any meaningful level of global sustainability, and we welcome theoretical, empirical, and methodological contributions from academics, non-academics, and combinations of the two. Urban governance speaks most obviously to researchers working in the field of urban studies, politics, human geography, and we hope to become the go-to publication space for new thinking on this topic, but sustainability is an inherently interdisciplinary challenge, and we encourage submissions from the full range of scientific, social scientific, and arts disciplines. Our hope is that the flexibility of submission formats, ranging from relatively short think-pieces to full research papers, will make it possible for more voices to join the debate that reflect the diversity of cities across the globe and stretch the boundaries of what it means to conduct research on urban governance and sustainability.

\section{AUTHOR CONTRIBUTIONS}

All authors listed have made a substantial, direct and intellectual contribution to the work, and approved it for publication.

\section{ACKNOWLEDGMENTS}

The author would like to thank the members of the Frontiers in Sustainable Cities Editorial board for their comments on a previous version of this editorial, and three reviewers for their detailed and transformative comments on a later version. The author would also like to thank colleagues at the Manchester Urban Institute and the International Institute for Industrial Environmental Economics at Lund for many interesting conversations and workshops on this topic over the past years. Final acknowledgments go to the European Union's Horizon 2020 research and innovation programme grant agreement number 646578 and the Formas Guest Researcher Programme that have supported the development of these ideas. All opinions stated herein are those of the author.

Chatterji, T. (2013). The micro-politics of urban transformation in the context of globalisation: a case study of Gurgaon, India. South Asia J. South Asian Stud. 36, 273-287. doi: 10.1080/00856401.2012.739272

Cugurullo, F. (2016). Urban eco-modernisation and the policy context of new ecocity projects: where Masdar city fails and why. Urban Studies 53, 2417-2433. doi: $10.1177 / 0042098015588727$

Elmqvist, T., Bai, X., Frantzeskaki, N., Griffith, C., Maddox, D., McPhearson, T., et al. (eds) (2018). The Urban Planet: Knowledge Towards Sustainable Cities. Cambridge: Cambridge University Press. doi: 10.1017/97813 16647554

Evans, J., Jones, R., Karvonen, A., Millard, L., and Wendler, J. (2015). Living labs and co-production: university campuses as platforms for sustainability science. Curr. Opin. Environ. Sustain. 16, 1-6. doi: 10.1016/j.cosust.2015.06.005

Evans, J., Karvonen, A., and Raven, R. (eds) (2016). The Experimental City. London: Routledge. doi: 10.4324/9781315719825 
Harvey, D. (1989). From managerialism to entrepreneurialism: the transformation in urban governance in late capitalism. Geografiska Annaler Ser. B. Hum. Geogr. 71, 3-17. doi: 10.1080/04353684.1989.11879583

Hoornweg, D., and Pope, K. (2017). Population predictions for the world's largest cities in the 21st century. Environ. Urban. 29, 195-216. doi: $10.1177 / 0956247816663557$

Karvonen, A., Cugurullo, F., and Caprotti, F. (eds) (2018). Inside Smart Cities: Place, Politics and Urban Innovation. Routledge. doi: 10.4324/9781351166201

Karvonen, A., and Van Heur, B. (2014). Urban laboratories: experiments in reworking cities. Int. J. Urban Region. Res. 38, 379-392. doi: $10.1111 / 1468-2427.12075$

Kearns, A., and Paddison, R. (2000). New challenges for urban governance. Urban Stud. 37, 845-850. doi: 10.1080/00420980050011118

Kitchin, R. (2014). The real-time city? Big data and smart urbanism. GeoJournal 79, 1-14. doi: 10.1007/s10708-013-9516-8

Kooiman, J. (ed) (1993). Modern Governance: New Government-Society Interactions. Sage.

Lim, H., and Taeihagh, A. (2018). Autonomous vehicles for smart and sustainable cities: an in-depth exploration of privacy and cybersecurity implications. Energies 11:1062. doi: 10.3390/en11051062

Martin, C. J., Evans, J., and Karvonen, A. (2018). Smart and sustainable? Five tensions in the visions and practices of the smart-sustainable city in Europe and North America. Technol. Forecast. Social Change 133, 269-278. doi: 10.1016/j.techfore.2018.01.005

Marvin, S., Bulkeley, H., Mai, L., McCormick, K., and Palgan, Y. V. (eds) (2018). Urban Living Labs: Experimenting With City Futures. Routledge. doi: 10.4324/9781315230641

Milakis, D., Van Arem, B., and Van Wee, B. (2017). Policy and society related implications of automated driving: a review of literature and directions for future research. J. Intell. Transport. Syst. 21, 324-348. doi: 10.1080/15472450.2017.1291351

OECD Publishing (2015). The Metropolitan Century: Understanding Urbanisation and Its Consequences. OECD Publishing.
Parnell, S. (2016). Defining a global urban development agenda. World Dev. 78, 529-540. doi: 10.1016/j.worlddev.2015.10.028

Patel, Z., Greyling, S., Parnell, S., and Pirie, G. (2015). Co-producing urban knowledge: experimenting with alternatives to 'best practice' for Cape Town, South Africa. Int. Dev. Planning Rev. 37, 187-203. doi: 10.3828/idpr. 2015.15

Polk, M., and Kain, J. H. (2015). "Co-producing knowledge for sustainable urban futures," in Co-producing Knowledge for Sustainable Cities (Abingdon: Routledge), 17-38. doi: 10.4324/9781315748030-1

Short, J. R. (ed) (2017). A Research Agenda for Cities. Cheltenham: Edward Elgar Publishing. doi: 10.4337/9781785363429

Trencher, G. (2019). Towards the smart city 2.0: empirical evidence of using smartness as a tool for tackling social challenges. Technol. Forecast. Soc. Change 142, 117-128. doi: 10.1016/j.techfore.2018.07.033

Trencher, G., Bai, X., Evans, J., McCormick, K., and Yarime, M. (2014). University partnerships for co-designing and co-producing urban sustainability. Glob. Environ. Change 28, 153-165. doi: 10.1016/j.gloenvcha.2014. 06.009

Valkering, P., Beumer, C., de Kraker, J., and Ruelle, C. (2013). An analysis of learning interactions in a cross-border network for sustainable urban neighbourhood development. J. Clean. Prod. 49, 85-94. doi: 10.1016/j.jclepro.2012.09.010

Conflict of Interest Statement: The author declares that the research was conducted in the absence of any commercial or financial relationships that could be construed as a potential conflict of interest.

Copyright (C) 2019 Evans. This is an open-access article distributed under the terms of the Creative Commons Attribution License (CC BY). The use, distribution or reproduction in other forums is permitted, provided the original author $(s)$ and the copyright owner(s) are credited and that the original publication in this journal is cited, in accordance with accepted academic practice. No use, distribution or reproduction is permitted which does not comply with these terms. 